\title{
Principle of Force Majeure - An Assessment of Commercial Contracts in India in Context of Covid -19
}

•Dr. Raj Kumar

•-Seema Deshwal

\begin{abstract}
For a while now, the world has been facing the catastrophic Covid-19 pandemic which not only impacted human lives but also adversely affected trade and commerce across the globe. The restrictive movements and government mandated lockdowns abruptly halted business operations of many sectors and put strain on economies of various nations in the world. Resultantly, the business entities struggled to fulfil their contractual obligations and look for a way out.

As the commercial turmoil continues, global focus shifted on concept of force majeure to ascertain liabilities of the affected parties as regards their contractual obligations. Although it was previously considered a superfluous inclusion in the commercial contracts, the force majeure has gained popularity in a short span. This research paper gives broad insight into the concept of force majeure, analyse its legal framework in India and outline significance of doctrine of frustration. The paper further examines the commercial contracts in India to assess if Covid-19 related disruptions can be treated as Force Majeure Events. This paper also includes comparative analysis from international perspective to comprehend the global stance on force majeure.
\end{abstract}

Keywords - Force Majeure, Covid-19, Contract Law, Doctrine of Frustration

\section{Introduction}

With the outbreak of Covid-19 pandemic across the globe last year, many countries including India had implemented nationwide lockdown and restricted movements of people as well transport to contain community spread of the pandemic except for the supply of essential goods and services. The pandemic not only adversely affected humans lives and health but also caused a huge blow to trade and commerce sector throughout the world. Global economy came at a grinding halt and many business houses faced challenges to continue their business activities amid government mandated lockdowns, work closures, restrictive movements, restriction on operating establishment, unavailability of good and services mainly attributable to supply chain disruption and resultantly finding it difficult to perform their contractual obligations.

Even though many of the countries in the world have developed vaccines for Covid-19, it's still many months that all of world's population get vaccinated due a variety of factors. On

- Head \& Dean, Faculty of Law, Baba Mast Nath University, Asthal Bohar, Rohtak

•- Research Scholar, Faculty of Law, Baba Mast Nath University, Asthal Bohar, Rohtak 
top of it, another variant of the covid virus has caused uproar in India this summer, taking numerous lives and once again halting the momentum of already crippled business.

The situation had given rise to uncertainty regarding performance of contracts, which may result into breach of contract or violation of provisions contained thereof. These unprecedented circumstances have led the contracting parties to assess their rights, remedies and exemption available to them under their respective contracts and in the law, in order to be absolved from the penalties accruing from non-performance of their contractual obligations. Recent state of affairs steered up several discussions around the world as to whether the pandemic related restrictions and resultant lockdowns constitutes Force Majeure event or not and whether to exonerate a party from non-performance of contract or performance of obligations under the contract have become so impossible as to institute the doctrine of frustration and how to deal with the repercussions thereof.

In light of the foregoing, it is essential to analyse ramifications of Covid-19 on contracts and examine the legal framework. This article aims to give broad insight in to the concept of force majeure and doctrine of frustration, distinction between the two and assess if Covid-19 can be regarded as a force majeure event in context of commercial contracts in India. A comparative analysis with some of the other nations in also carried out to get an international perspective.

\section{Concept of Force Majeure}

Force Majeure is a contractual risk allocation mechanism generally incorporated in the contracts to deal with situations where performance of the contract is suspended or becomes impractical, due to unavoidable and unforeseen events, which are not in contracting party's control. In general terms, Force Majeure is referred to as Major Force or Irresistible Force beyond the control of humans. Provision of force majeure is intended to excuse nonperformance by parties induced only by any supervening event and not their negligence or other malfeasance.

Force Majeure is a civil law concept, mostly recognized in common law jurisdictions. Although its origin is Roman, it rose out of two opposing legal principles (Pacta Sunt Servanda and Rebus Sic Stantibus) prevalent in the merchant's law of early Roman Empire ${ }^{1}$. The civil law countries eventually familiarized themselves with this legal concept and is most notably found today in the French Civil Code (Article 1147 and 1148) dating back to $1804^{2}$, also known as Napoleonic Code. It is one of the oldest codifications that still exist today.

\footnotetext{
${ }^{1}$ Richard Hyland, "Pacta Sunt Servanda: A Meditation”, 34 Vanderbilt Journal of Transnational Law 412 (2001).

${ }^{2}$ French Civil Code, 1804, art. 1147, 1148, 1348, 1631, 1730, 1733, 1754, 1784, 1929, 1934, 1954.
} 
Merriam Webster's Law Dictionary defines force majeure "as superior strength that is unforeseeable and unavoidable outside the control of a party to a contract that render it incapable of carrying out contractual duties". 1

Force Majeure is French word for superior force Black's Law Dictionary defines it as "an event or effect that can neither be anticipated nor be controlled. The term includes both act of nature (e.g. floods and hurricanes and act of people (e.g. strike, riot and war)". ${ }^{2}$

It is commonly understood that the events caused by any major force (natural or artificial), which are unforeseeable and unavoidable, are characterised as force majeure events.

\section{Vis Major (Act of God)}

'Vis Major' is a Latin word, meaning act of God and further defined as an "a greater and superior force - a natural and inevitable necessity, and one arising wholly above the control of human agencies, and which occurs independently of human action or neglect". 3 Acts of God are considered to be natural calamities free from human intervention.

Force Majeure had wider ambit than Vis Major as the former comprehends both natural and artificial unforeseen events whereas the latter contemplates only natural unforeseen events. In practical approach across industries, Vis Major is actually considered as a sub-set of Force Majeure. The Supreme Court of India has recognised the distinction between Vis Major and Force Majeure in Dhanrajamal Gobindram v. Shamji Kalidas \& $\mathrm{Co}^{4}$

\section{Doctrine of Frustration}

Doctrine of Frustration is a widely recognised principle in Indian contract law, which stipulates complete impossibility, impracticability or unlawfulness of the performance of the contract, which the parties had not contemplated at the time when they entered into the contract. If it is established that the force majeure circumstances have materially affected the performance of obligations and there is no way to continue the contract while such circumstances exist, the contract is considered be void and both contracting parties are discharged of their respective obligations and neither party has the right to sue the other party for breach of such contract or payment of damages. However, where time is not essence of the contract and the parties are capable of performing their respective obligation when such force majeure event is over, such delay in performance shall not be considered as frustration of contract.

\section{Contracts in India \& Force Majeure}

\footnotetext{
1"force majeure," Merriam-Webster.com Dictionary, available at https://www.merriamwebster.com/dictionary/force\%20majeure>, accessed on $7^{\text {th }}$ May 2020.

${ }^{2}$ Bryan A. Garner and Henry Campbell Black, Black's Law Dictionary, 1914 (St. Paul, MN: Thomson /West Group $8^{\text {th }}$ Edition, 2004).

${ }^{3} I d$ at 101 .

${ }^{4}$ AIR 1961 SC 1285.
} 
In this section, legal provisions, prevalent practise of force majeure clauses, assessment of Covid-19 as force majeure, condition precedent to invoke the defence and relevant judicial trends in Indian framework are outlined.

\section{Governing Law}

Reciprocal obligations of the parties are foundation of the contract law. Section 37 of the Indian Contract Act 1872 ("Contract Act"), lays down that "the parties to a contract must either perform, or offer to perform, their respective promises, unless such performance is dispensed with or excused under the provisions of this Act, or of any other law".

Although the term force majeure has neither been defined nor specifically dealt with under India law, some reference can be found in Section 32 (Chapter III) of the Contract Act, dealing with contingent contracts, precisely a term or provision which is enforceable upon happening of an uncertain future event. The plain reading suggests that if there is an express or implied clause in a contract stipulating unforeseeable events and provides for consequences thereof, it is governed by Section 32 of Contract Act.

The other provision i.e. Section 56 of the Contract Act provides that an agreement to do an act impossible in itself is void and that a contract which, after executing, becomes impossible or unlawful to perform due to an intervening event becomes void in law, thereby absolving the parties from performance of their contractual obligations or penalty imposition.

Section 32 becomes applicable in the cases where express provisions in the contracts covering the force majeure or supervening events and their consequences are incorporated allowing parties to claim temporary suspension or postpone performance whereas Section 56 provides relief where there is complete impossibility of performance of contract due to the force majeure event, causing frustration of contract.

Hon'ble Supreme Court of India in Satyabrata Ghosh v. Mugneeram Bangur, ${ }^{1}$ acknowledged that when a force majeure event is relatable to an express or implied clause in a contract, it is governed by Section 32 of the Contract Act whereas if a force majeure event occurs dehors the contract, Section 56 of the Contract Act applies.

Restitution of the contract is one of the consequences of frustration of a contract whereby parties are to be put in the same position as they were if the contract had never been executed. The concept of restitution as set out in Section 65 of Contract Act states that when an agreement becomes void, as in case of a frustration of contract, the party who has received any advantage under such agreement is bound to restore it or compensate for it; from the party it had received such advantage. Therefore, when a contract is frustrated, the consideration received from the other party must be repaid. ${ }^{2}$

\footnotetext{
${ }^{1}$ AIR 1954 SCR 310.

${ }^{2}$ Bombay Dyeing and Manufacturing Co. Ltd.v. State of Bombay, 1958 SCR 1122 : AIR 1958 SC 328;
} 


\section{Force Majeure Clauses in Indian Contracts}

Different contracts are drafted in different manner; nonetheless, similarity between industry specific contracts is natural. For instance, a force majeure clause in automobile or retail sector contracts are expected to cover similar exemption causes which dominates the automobile or retail sector respectively. An overview of commercial contracts drafted in India will reveal that a force majeure clause is typically found as standard or boilerplate clause in most contracts. Most common events defined as force majeure in these clauses generally include acts of God, war, government action, terrorism, lock-out, strikes, floods, earthquakes, and other natural calamities, upon occurrence of which the contracting party shall be entitled to suspend their performance agreed under the contract, however, the word 'Pandemic' is mostly left out of force majeure purview.

Contracts often contain exception clauses that provides exhaustive list of causes and events to be treated as force majeure for the sake of said contract, these are known as Specific Force Majeure Clauses (exhaustive) and leaves no scope for further interpretation or inclusion of any other inevitable event. Another type of common clause incorporated in contracts, known as Catch All Phrase Clause (non-exhaustive), is drafted as an open-ended clause and generally contain language like "including but not limited to" or "similar other events" or "any cause or event outside the reasonable control of the Parties". Be it specific or catch all, aim of the force majeure clauses is to claim provisional deferment or avoid penalties for contractual non-performance to affected party.

A superlative clause of force majeure must clearly incorporate the list of supervening events to be treated as force majeure in context of said contract, duration of such events, service of notice, timelines involved, steps for resolution or risk mitigation, consequences arising there from and elimination of uncertainties regarding performance.

Some of the contracts do not contain exemptions for non-performance either in the nature of force majeure or exception clauses or any similar provisions to provide for an untoward incident that has made performance of the contract impractical or permanently impossible; in such situation doctrine of frustration comes into play and such contracts are dealt with under Section 56 of the Contract Act ${ }^{1}$. In the matter of Mugneeram Bangur \& Co. Vs. Gurubachan Singh, ${ }^{2}$ the Apex Court held that temporary impossibility in performance of obligations under a contract does not automatically discharge the contract, therefore, delay in performance shall not be construed as frustration of contract unless time is essence of the contract.

\section{Assessment of Covid-19 as Force Majeure Event in Context of Commercial Contracts in India}

Undoubtedly, spread of Covid-19 and consequent situation arising there from is impairing the abilities of contracting parties to perform their obligations, however, the debatable question is

\footnotetext{
${ }^{1}$ Naihati Jute Mills Ltd. v. Khyaliram Jagannath, AIR 1968 SC 522.

${ }^{2} 1965$ AIR 1523, 1965 SCR (2) 630.
} 
whether the restrictions and lockdowns arising out of Covid-19 can be categorised as a force majeure event or not and the answer is contingent on different variables of its collective impact. An attempt in this article is made to clear the prima facie situation in context of contractual provisions in India.

Ministry of Finance, Indian Government on $19^{\text {th }}$ February, 2020, issued an office memorandum to all central Government Ministries that any disruption caused in supply chain due to spread of Covid-19 will be considered as natural calamity under force majeure clauses. ${ }^{1}$ Though this is a direction to government ministries and departments, the relief may be extended to companies or partners working with government and may also serve an indication for private sector. It was further clarified that contractual performance shall be suspended only to the extent as affected by pandemic and not in entirety.

Similarly, Ministry of New \& Renewable Energy, Indian Government vide an office memorandum on $20^{\text {th }}$ March 2020 concerning solar project developers, stated that if parties fail to meet contractual obligations because of Covid-19, they can invoke the force majeure Clauses wherever necessary, after following due procedure. ${ }^{2}$

Earlier, the Supreme Court of India had issued guidelines to analyse an event to qualify as force majeure and for the parties to seek relief under the same, in the case of Energy Watchdog v. Central Electricity Regulatory Commission \& Ors. ${ }^{3}$ In this case, the Apex Court had stated that the ambit of force majeure cannot be stretched to a probable difficulty or financial loss caused to the entity obligated to perform the contract and further laid down the following guidelines to be paid attention to, while invoking a force majeure clause:

1. Event occurred should be inevitable, unforeseeable at the time of contracting and beyond the reasonable control of the parties;

2. Non-performance is caused by said inevitable events or circumstances;

3. Best possible efforts were undertaken to mitigate impact of such force majeure event.

4. Such event has actually rendered the performance impossible or illegal.

Thus, in the wake of aforementioned guidelines, it can be analysed that Covid-19 pandemic, the restrictive measures taken, lockdown and its impact on the business was unforeseeable, inevitable and is an impediment, impracticability or impossibility in performance of the contractual obligations. The inter-departmental guidelines (supra) from Central Govt. Ministries have also treated Covid-19 as force majeure event. However, the parties seeking to rely on exemption of force majeure must demonstrate direct impact of Covid-19 on disruption of their contractual obligations; their efforts to mitigate the impact and that alternate means of performance are not left.

Conversely, the parties cannot seek benefit if they were able to somehow continue operations, either digitally or partially and they could complete their obligations in an extended time,

\footnotetext{
${ }^{1}$ No. F18/4/2020-PPD, Ministry of Finance, Government of India

${ }^{2}$ No. 283/18/2020-GRID SOLAR, Ministry of New \& Renewable Energy (MNRE), Government of India

${ }^{3} 201714$ SCC 80
} 
post the lockdowns in their respective city. Therefore, seeking blanket protection of pandemic or lockdown even when not applicable is incorrect and not utilising alternative ways to perform may lead to disputes between contracting parties.

\section{Judicial Trends}

In the early twentieth century, the judiciary had dealt with certain incidents beyond the control of humans and their ramifications on the performance of contracts. Impacts of Covid19 have unearthed slowly and some of the leading cases will be worth discussing on the subject matter.

One such case Halliburton offshore Services Inc. v. Vedanta Limited \& Anr., ${ }^{1}$ came up before the Delhi High Court wherein protection under force majeure was sought by the petitioner. In this case the petitioner sought injunction against encashing bank guarantees furnished by the petitioner to the defendants in support of a development work contract executed between the two. The petitioner moved an application seeking relief of interim injunction arguing that owing to the complete lockdown and restrictive movement consequent to Covid-19 pandemic during first quarter of 2020, the petitioner was unavoidably handicapped in performing its part of the contract. The Court allowed the prayer of the petitioner and acknowledged that such a lockdown is unprecedented and is in nature of force majeure, none of the parties were capable of predicting this event and hence it is only equitable to allow ad-interim relief only until one week after the lockdown is over.

Although on the next hearing Court sought monthly project development reports and observed that petitioner did not adhere to the project deadlines even prior to outbreak of Covid-19 and has delayed project completion even after extended timelines given by the defendant. Therefore, the ad-interim stay so granted was vacated and the petition was disposed of on $29^{\text {th }}$ May 2020.

Another such instance is when Bombay High Court refused to grant an injunction as prayed collectively by five steel importers (petitioners) in Standard Retail Private Limited v. M/s G.S. Global Corp \& Ors. ${ }^{2}$ The Court noted that the force majeure clause was contained in the principle Sale Contract and not in the ancillary letters of credit. It was observed that there was no restriction on movement\& distribution of steel, being categorized as essential service as per notifications of Indian Government. Further, it was observed that lockdown is for a limited period of time and a temporary restriction therefore not justifiable ground for terminating the contract. The court also noticed that the language of force majeure clause in the contract intended to aid only the sellers and not the importers and also the letter of credit was considered to be an independent transaction than that of contract of sale of steel. Therefore, the Bombay High Court refused to grant any ad-interim reliefs to the petitioners stating that the respondent bank was well in its right to encash the letters of credit.

${ }^{1}$ O.M.P. (I) (COMM) \& I.A. 3697/2020

${ }^{2}$ Order dated $8^{\text {th }}$ April, 2020 passed by the Bombay High Court in Commercial Arbitration Petition (L) No. 404 of 2020 
In the matter of Ramanand and Ors v. Dr. Girish Soni \& Anr., ${ }^{1}$ Delhi High Court have clarified its view on implication of force majeure in absence of contractual relationship. In the present case, the tenant was holding the commercial premises at Khan Market, Delhi at a meagre rent of Rs. 300/- per month vide a lease deed executed on $1^{\text {st }}$ February 1975. An eviction petition brought by landlord in 2008 was allowed by the rent controller in 2017 . Delhi High Court stayed the eviction in the review petition filed by landlord, on payment of monthly rent of Rs. 3.5 Lacs. The tenant moved an urgent application for suspension of rent in May, 2020 before Delhi High Court. In order to settle the legal position, the court observed variety of factors such as nature of property, amount of rent and protection extended by executive orders and concluded that there was no rent agreement or lease deed between the Parties and in view of decree of eviction, the tenant was unauthorised occupant. In absence of any contractual obligation between the Parties, neither protection of force majeure was available to the tenant nor his case is covered under Section 180(B)(e) of Transfer of Property Act, 1882 but only governed by the provision of Delhi Rent Control Act, 1958.In light of the facts and circumstances of the present case, Justice Pratibha M. Singh was of the view that case of suspension of rent was not made out hence rejected application of the petitioner tenant, however, only given some relaxation in the schedule of payment due to lockdown.

It may be relevant here to take a look at the judicial views of the other nations, which had previously taken into considerations situation arising out of epidemics and pandemics and have granted or refused relief from non-performance of contract to the parties.

One such notable case is Li Ching Wing v. Xuan Yi Xiong ${ }^{2}$ (also known as SARS Case) decided by the Hong Cong Court in 2004 relating to outbreak of SARS epidemic. The plaintiff challenged termination of domestic lease by the defendant. The plaintiff contended that he had to vacate the flat on the account of outbreak of Severe Acute Respiratory Syndrome (SARS) in the building on $29^{\text {th }}$ March 2003 followed by 10 days isolation (until $10^{\text {th }}$ April 2003) of the said building block by the Department of Health, allowing residents to return to their flats afterwards.

The Court rejected the claim of the defendant (tenant) that the contract has frustrated and held that the isolation order lasted for 10 days and was quite insignificant a period in terms of the overall use of the premises for a term of two years. The Court also denied the plea taken by the defendant that due to the SARS outbreak, the demised premises became inhabitable and warrants repair, in absence of which the lease was bound to be terminated. The Court states the defendant failed to show that there was an implied term as to habitability throughout the term of the tenancy.

North Dakota Supreme Court in Sandry v. Brooklyn School District No. 78 of Williams County ${ }^{3}$ held that a school district was excused from paying a driver for his services during the school closure

${ }^{1}$ RC. Rev. 447/2017, Delhi High Court

${ }^{2}$ [2004] 1 HKC ; [2004] 1 HKLRD 754 ; [2004] HKC 353

${ }^{3}$ Sandry v. Brooklyn Sch. Dist. No. 78 of Williams County, 182 N.W. 689, 690-91 (N.D. 1921);

April Farris and Heaven Chee, Contract Performance During Pandemic: Lessons From 1918 published on $17^{\text {th }}$

April 2020, available at< https://www.law360.com/articles/1264775/contract-performance-during-pandemiclessons-from-1918>, accessed on $12^{\text {th }}$ May 2020. 
during outbreak of Influenza, by determining that the pandemic was an Act of God and that nonpayment be exempted.

Whereas, in Lakeman v. Pollard, ${ }^{1}$ a workman at a mill left his job early during a cholera epidemic due to concerns of contracting the disease and thus failed to complete his work contract. In an action by the mill owners seeking compensation for work done by the labourer, it was argued that the work contract had been breached. The Supreme Court of Maine held that the cholera outbreak was an Act of God and the labourer was thus not in breach of his contract since duty to perform under the contract was discharged.

Fundamentally, there is no 'one size fits all' answer when it comes to applicability of force majeure but the tailor made provisions in the contracts have huge role to play. While a Court may grant equitable relief such as temporary injunctions, the threshold for meeting Force Majeure and Doctrine of frustration criteria is very high and shall be viewed on case to case basis, in light of the rationale laid down by the Supreme Court of India. ${ }^{2}$

\section{Condition Precedents to invoke defence of Force Majeure}

In modern business practice, force majeure clauses are embodied in the form of contractual provisions after deliberate discussions between parties as potential route out of difficulties in the events beyond their control. Evidently, force majeure is not available as an absolute protection but language negotiated and incorporated in the clause is of utmost importance to determine the remedies available, if it provides for immediate termination or only some of the obligations can be suspended or the contract itself can be put on hold.

If the words 'epidemic' or 'pandemic' are specifically used in the exemplified force majeure clauses, then in all likelihood, the force majeure clause is triggered under the contract with the declaration of Covid-19 as a pandemic.

However, where the force majeure clauses list out only specific events and the word 'pandemic' in not included explicitly therein the word used such as 'Govt. Orders/Actions/Notifications' or 'Lockdown' can be construed to include the aftermaths of Covid-19 pandemic and its bearings on the contracts. In the non-exhaustive clauses, interpretation of the terms used therein is critical in determining remedies and course of action such as the clause starting with the terminology 'including but not limited to' or has 'similar other events beyond the control of the Parties' in them, can be construed to include the current pandemic and its aftermaths having direct impact.

Radically, the pandemic breakout alone is not force majeure but the resulting situation and its impact on business may be and it is arguable to take shelter of force majeure, wherever the pandemic has prevented, impeded or delayed the contractual performances. Onus of proof is on the invoking party and it order to seek reliance on force majeure for the current state of affairs, the affected party must exhibit that the pre-requisite essential conditions are fulfilled:

\footnotetext{
$143 \mathrm{Me} 463$ (1857)

${ }^{2}$ Energy Watchdog Vs. Central Electricity Regulatory Commission \& Ors; 201714 SCC 80
} 
1. that at the time of executing the contract, it did not foresee the current Covid-19 pandemic;

2. that the lockdown situation arising out of this pandemic was inevitable, unavoidable, resulted from a supervening event and beyond the control of the Parties;

3. that the pandemic and resultant government enforced lockdowns and other restrictions had directly impacted its business and is a hindrance in performance of its obligations;

4. that it has taken all reasonable steps, be it commercial or financial in nature, for example disbursing more money, hiring extra manpower, seeking alternative manufacturing lines or suppliers, etc., to overcome or mitigate the impact of the Covid-19 and its consequence;

5. that despite taking alternative recourses, no other means for performing the obligations under the contract are left and the event has rendered the contract impossible to perform temporarily or permanently;

6. that parties must have resorted to procedure stated in its contract regarding service of notice to the other party intimating intention to invoke the force majeure and compliance with all of the above conditions is complete.

It is notable that the force majeure does not intend to provide relief in case of intentional laxity or other misdoings of a party; however, if any party is truly affected by this unexpected event, it is prudent that instead of litigating, the parties may renegotiate their obligations and liabilities under the contract. The Parties can be temporarily relieved from their liabilities or performance can be postponed or granted extension if capable of being performed after some time such as construction of a building after the lockdown is over. The affected party may not be held liable to pay damages for delay but the contract shall still have to be performed by that party as may be decided by the parties involved.

Another pertinent question arises whether a party can be completely absolved of their obligation where the contract has become impossible or impractical to perform due to the pandemic such as a contract to organise an event, which stands cancelled due to the restrictions imposed by the government on gathering of more than 5 persons consequent to pandemic. The answer would be fact specific determination based on intruding factors. The impossibility to perform the contractual obligation has frustrated the contract and delay in performance or grant of extension will not achieve redemption of the contract hence the parties may choose to mutually end the contract or act in accordance with the embodied force majeure clause or take recourse to Section 56 of the Contract Act.

Impact of Force Majeure on Commercial Contract in Comparative Jurisdictions (UK, China, Russia \& USA)

\section{United Kingdom}

Force majeure has neither any technical legal meaning in English or Scottish law nor is it a general principle of common law but it's meaning majorly is a matter of contractual interpretation. The parties shall have to expressly mention the instances of force majeure in 
the contract itself, for which they wish to get the relief for, else scope in law is very limited to provide any relief to defaulting party.

Whether a particular clause relieves a party of contractual liability, under English and Scots law, depends on the precise wording used in the clause, the allocation of risk between the parties provided for by the contract as a whole, the circumstances in which the parties entered into the contract, and the situation that has arisen. ${ }^{1}$ If the contract does not provide any such routes, it may in certain circumstances be possible to rely on the doctrine of frustration of contract.

Earlier, in Tennants (Lancashire) Ltd v. C S Wilson And Co Ltd, House of Lords decided that due to outbreak of war in 1914, the chemical in question was unavailable, while the rise in the price was not a hindrance to delivery but actual shortage of chemical was sufficient to hinder the delivery. The contingencies affecting performance of the contract between plaintiff and respondent specifically contained "war" as one of the conditions, thus the stipulation became operative and suspension of the contract was justified. ${ }^{2}$

Taking suo moto cognizance of the situation arising out of Covid-19, United Kingdom passed two laws to deal with the pandemic and provide relief to its citizens and trade, namely; Coronavirus Act, 2020 and Coronavirus (Scotland) Act, 2020 ${ }^{3}$. It is natural for the affected parties to rely on contractual force majeure clauses in the aftermath of lockdown measures, but then wherever relevant contractual provisions are unavailable, some relief can be sought in the relevant legislation (supra).

\section{China}

The contract and civil law in China define force majeure as events that are unforeseeable, unconquerable and unavoidable, that prevents the parties from fulfilling their contractual obligations. China was the first country to be hit by the virus and close its cities for business in December'2019; however, it quickly resumed business in March'2020 and had officially acknowledged Covid-19 as force majeure event affecting human lives and commerce not only in China but on a global scale.

The China Council for the Promotion of International Trade (CCPIT), in an international communication dated $30^{\text {th }}$ April 2020, released on its website had stated that those difficulties that once encountered by Chinese enterprises have now emerged in front of enterprises in other countries. ${ }^{4}$ CCPIT had issued force majeure certificates (certifying Covid-19 as a force majeure event), to Chinese enterprises as well as foreign chambers and associations

\footnotetext{
${ }^{1}$ Faye Moore, Will Covid-19 trigger a force majeure clause, published on $26^{\text {th }}$ March 2020, available at <https://www.pinsentmasons.com/out-law/guides/covid-19-force-majeure-clause>accessed on 13 ${ }^{\text {th }}$ May 2020. 21917 UKHL 523, 55 SLR 523

${ }^{3}$ Legislation available at https://www.legislation.gov.uk/ukpga/2020/7/contents

${ }^{4}$ China Council for the Promotion of International Trade, International Communication released on Force Majeure Certificates, released on $30^{\text {th }}$ April at $<$ https://en.ccpit.org/infoById/40288117668b3d9b0171c8e0ef5408a2/2 >accessed on $15^{\text {th }}$ May 2020 and $3^{\text {rd }}$ June 2021.
} 
operating in China to help enterprises retain their orders, postpone deliveries, exempt relevant liabilities and cope with the impact of the pandemic. It should be noted that the acquisition of the certificate does not necessarily entail that the virus-hit enterprise can be exempted from the contract liability in whole or in part, ${ }^{1}$ although it may serve as evidence in cases of dispute.

CCPIT had further advised the Chinese companies to fully understand the plight of their counterparts and assess if they have performed the duty of informing and loss reduction in accordance with their contracts and if needed, shall conduct friendly negotiations and seek alternative solutions on the basis of mutual understanding. As of $20^{\text {th }}$ April, 2020, through a total of 105 Commercial Certification Authorities of the National CCPIT system had issued 7004 force majeure certificates, involving contracts amounting to about RMB 690 billion. $^{2}$ Later, China resumed full scale production and the elements causing difficulty in performance were gradually eliminated, hence decline in demand to obtain the force majeure certificates.

\section{Russia}

Article 401 of the Russian Civil Code (RCC) states that unless otherwise provided by the contract, a person shall not be liable for non-performance or undue performance of its obligations assumed in the course of its entrepreneurial activities, if the performance of these obligations is impossible due to an "irresistible force" i.e. an extraordinary and unavoidable event in the given circumstances (force majeure). ${ }^{3}$ The RCC does not provide a list of circumstances that qualify as force majeure, but stipulates which circumstances cannot be regarded as force majeure.

In light of the Covid-19 and surrounding uncertainty, the Presidium of the Supreme Court of the Russian Federation, on $21^{\text {st }}$ April, 2020 issued an overview on a range of issues in various areas of law including judicial practice, dispute resolution and contractual obligations in Russian context of Covid-19 pandemic and restrictive measures (Overview). ${ }^{4}$ The Overview clarified that spread of the Covid-19 shall not be commonly treated as a force majeure event for all situations rather be examined on case to case basis.

The take away from the overview is that if any party is seeking suspension of contract or want to absolve itself of its liabilities, the debtor/obligor under the contract will have to prove the presence and duration of a force majeure event, its extraordinary and unavoidable nature, causal relationship between the force majeure event and the impossibility or delay of

\footnotetext{
${ }^{1}$ Ibid.

${ }^{2}$ Ibid.

${ }^{3}$ Civil Code of Russian Federation 1994, Article 401.

${ }^{4}$ Laura Bank, Maryana Batalova, et.al., COVID-19 Coronavirus: Russia's Supreme Court Provides Clarifications on the Impact of COVID-19 related measures on Contract Performance and Dispute Resolution, published on $24^{\text {th }}$ April 2020, available at <https://info.dechert.com/10/13963/april-2020/covid-19--russia-ssupreme-court-provides-clarifications-on-the-impact-of-covid-19-related-measures-on-contract-performanceand-dispute-resolution.asp?sid=d8e979b4-bda0-4f96-bae0-8353b48c3892>, accessed on 15 ${ }^{\text {th }}$ May 2020.
} 
contractual performance, the party's lack of involvement in the creation of the force majeure event, the conscientious adoption by the party of any reasonably expected measures to prevent (or minimize) possible risks. ${ }^{1}$ Performances of such contracts shall be resumed upon termination of such force majeure event.

Determination of an exemption due to a force majeure event is left for the Russian courts, which may take into account acts of the state authorities, relevant documentation, correspondence, witnesses' evidence to confirm the presence of the force majeure event [e.g. force majeure certificate issued by the Chamber of Commerce and Industry of the Russian Federation (CCIRF) in the context of the Covid-19 outbreak through a hotline made operational on $18^{\text {th }}$ March 2020 for said purpose]. ${ }^{2}$

Accordingly, Covid-19 pandemic and the restrictive measures to control its spread were recognized as grounds for amending/terminating a contract in Russia only in exceptional cases, based on the interpretation of a force majeure clause and its application thereof.

\section{United States of America}

During the first wave of Covid-19, evidently United States of America (USA) was the third most affected country by the corona virus disease and New York City, the economic capital of USA, was most vulnerable. Restrictive movements, temporary lockdown and business closure in US put a huge dent in US Economy. As a result thereof, performance under many contracts involving US companies got delayed, interrupted, and even cancelled, which led the affected companies to fish their contracts to exonerate themselves of penalties under in-built force majeure clauses.

The New York Uniform Commercial Code (NY UCC) governs law as regards the commercial contracts and similar to English Common Law it gives weightage to strict interpretation of the force majeure clauses as embodied in the contracts. Some jurisdictions, including New York, Delaware excuse performance only where it is truly impossible, rather than merely impracticable, which generally requires a showing that destruction of the subject matter of the contract or the means of contractual performance make the satisfaction of obligations impossible. ${ }^{3}$ In the event that the parties to a contract disagree as to whether Covid-19 constitutes a force majeure event, it is ultimately up to the Courts to decide the parties' rights and obligations, ${ }^{4}$ which is a matter of contract interpretation governed by state law.

\footnotetext{
${ }^{1}$ Ibid.

${ }^{2}$ Chamber of Commerce and Industry of the Russian Federation, Announcement on $26^{\text {th }}$ March 2020, available at $<$ https://tpprf.ru/en/announcements/-i35129 9/>, accessed on $15^{\text {th }}$ May 2020.

${ }^{3}$ Kel Kim Corp. v. Cent. Mkts., Inc., 70 N.Y.2d 900, 902 (1987)

${ }^{4}$ Baker Mckenzie, When is force majeure really a force majeure?, published on $5^{\text {th }}$ March 2020, available at <https://www.bakermckenzie.com/en/insight/publications/2020/03/when-is-force-majeure-really-forcemajeure $>$, accessed on $16^{\text {th }}$ May 2020.
} 
Express inclusion of the "pandemic" under force majeure clause is essential to constitute a force majeure for Covid-19, however, clauses not having reference on pandemics, epidemics, or other viral disease outbreaks are expected to be insufficient for invoking force majeure defence in Covid-19 outbreak, unless the courts adopt a liberal approach for analysis of existing situation. Terminology of a force majeure clause in contracts including the language such as "action of government", "other of similar character" or "for any reason beyond the control of the Parties" also paved way for postponement of the contractual performance. The force majeure clause can also include notice, duration, and mitigation requirements and alternative performance that must be met or followed to excuse non-performance ${ }^{1}$ (necessity test). Where there is no provision of force majeure in any contract, the parties can rely on doctrine of frustration with approval of the concerned jurisdictional court.

Thus, Covid-19 and relevant restrictions can be qualified as a force majeure event to invoke defence of the same and doctrine of frustration in USA, only if the parties can prove that the necessity test is passed.

\section{International Contracts and Force Majeure}

In cross country business transactions, the contracting parties are generally at liberty to choose jurisdiction or governing law for their contracts, in such contracts the terminology of incorporated force majeure clauses is determining factor to trigger entitlement of relief. Wherever, the contracts are sans force majeure clause, the contracts are likely to be interpreted in light of United Nations treaties. In the international transactions, force majeure certificates issued by some of the nations would not automatically satisfy the test for force majeure for a contract but they may only hold evidentiary value in support of the affected party's force majeure claim, but the specific requirements of the force majeure provision must still be satisfied.

While it is judicious for the parties to engage a compassionate outlook to find an amicable solution instead of creating a dispute, each transaction will be scrutinised in light of its own circumstances, terminology of contract, governing law and how the courts answers questions surrounding these aspects in different jurisdictions.

\section{Conclusion \& Way Forward}

Covid-19 pandemic is an unprecedented event, which surged the disputes pertaining to performance and invocation of defence of force majeure and frustration in commercial contracts in India. The parties seeking relief from the contractual obligations in light of Covid-19 pandemic; are not guaranteed success in taking coverage of Section 56 or of force majeure. Role of the Courts has been undeniably vital in taking pragmatic approach while dealing with contracts as regards liberal interpretation, dynamically ascertaining the

\footnotetext{
${ }^{1}$ Winthrop \& Weinstine, Covid-19 Impact on Contracts, available at < https://www.winthrop.com/boldperspectives/covid-19-impact-on-contracts/>, accessed on $16^{\text {th }}$ May 2020.
} 
impracticalities, establishing link between pandemic and non-performance, mitigation efforts, granting temporary injunctions etc., wherever force majeure is pleaded.

Covid-19 is a short-term impediment, which shall stand cured with time. Since this is not permanent impossibility hence invoking force majeure clauses where time is not essence of contract appears as a rescue measure and will save manifold litigation. Grating extension of time for performance or withholding performance until feasible except for time-bound contracts is also an alternative resolution. However, for the purpose of Section 56 of the Contract Act, a contract will stand frustrated on account of this pandemic only if time was the essence of the contract.

To manage the risks and impact of Covid-19 on contractual obligations, before pleading the parties can take proactive actions by:

(1) carefully examine the terminology of force majeure and other exemption provisions such as limited liability or exclusion clauses in their respective contracts and as available in law to determine if pandemic is included as a force majeure event or the language employed in the clause is open for inclusion of Covid-19 as force majeure;

(2) scrutinize their respective contracts to determine what rights and remedies are available to them in such circumstances;

(3) take in to consideration such aspects under the contracts which can be performed so as to avoid any dispute and satisfy themselves that performance is directly hindered due to the pandemic and no other means of performance are left;

(4) fulfil all procedural requirement as set out in the agreement such as timely notifying the other party of occurrence of the pandemic and demonstrating extent of adverse effect of pandemic on performance of its obligation;

(5) evaluate business sustainability and consider making appropriate efforts to avoid or mitigate the risk and impact of pandemic on their work performance;

(6) collect documentary evidences relating to force majeure such as government declarations and policies issued in relation to Covid-19, correspondence between the contracting parties etc. for a potential lawsuit;

(7) keep up with regulatory actions and notifications, public policies to monitor if they affect their contractual commitments;

(8) parties involving in interrelated or back to back contracts must assess overall impact on their obligation in all the contracts collectively and should have meticulous approach to differently interpret the force majeure provisions where different laws govern such back to back or interrelated contracts and with careful consideration take protective measures to safeguard their interest.

It is important to establish that a party has done all that was reasonably possible to mitigate the losses. The Parties also have an option to take legal opinions on whether the force majeure clause in their contracts is open ended or exhaustive and whether the relevant chain of events is excluded or covered there under. In other cases, fate of the contracts largely depends on the negotiations and attitude of the parties involved whether they would like to 
reschedule, waive damage claims and resume contracts when feasible or plead frustration of the contracts.

All contracts are different from one another and cannot be measured by same yard stick hence case to case basis review would be required based on various factors discussed hereinbefore. It has become fairly clear that inclusion of force majeure clause used to be considered as superfluous, nut now requires strict attention as to how it is drafted, analysed and interpreted as the Covid-19 outbreak has triggered sufficient alarm bells.

On a concluding note, it is recommended that instead of drawing light from Section 32 of the Contract Act, need of the hour is to have a specific codified law in India concerning force majeure events dealing with various contractual aspects, until then parties should adopt meticulous approach while including a force majeure clause in their contracts and dealing with the same thereafter. 